\title{
Vitamin D regulation of immune function during covid-19
}

\author{
Daniel D. Bikle ${ }^{1}$
}

Accepted: 20 December 2021 / Published online: 29 January 2022

This is a U.S. government work and not under copyright protection in the U.S.; foreign copyright protection may apply 2021

\begin{abstract}
Covid-19 has to date infected a confirmed 275 million people with 5.4 million, now dead, with the count rising every day. Although the virus, SARS-CoV2, causing Covid-19 infects many cells in the body, its infection of the upper and lower respiratory tract (upper airway epithelia and pulmonary alveolar pneumocytes and macrophages) causing what is now called a cytokine storm in the lungs is the major cause of morbidity and mortality. This results from a dysregulation of the innate immune system with an outpouring of proinflammatory cytokines and chemokines leading to abnormal activation of the adaptive immune pathway. Airway epithelia constitutively expresses CYP27B1, the enzyme producing the active vitamin D metabolite, $1,25(\mathrm{OH})_{2} \mathrm{D}$, and the vitamin $\mathrm{D}$ receptor (VDR) for which $1,25(\mathrm{OH})_{2} \mathrm{D}$ is the ligand. Pulmonary alveolar macrophages, on the other hand, are induced to express both CYP27B1 and VDR by various pathogens including viruses and cytokines released from infected epithelia and other immune cells. Although not demonstrated for corona viruses like SARS-CoV2, for other viruses and other respiratory pathogens activation of innate immunity leading to increased local $1,25(\mathrm{OH})_{2} \mathrm{D}$ production has been shown to enhance viral neutralization and clearance while modulating the subsequent proinflammatory response. Whether such will be the case for SARS-CoV2 remains to be seen, but is currently being proposed and investigated. This mini review will discuss some of the mechanisms by which vitamin D may help reduce morbidity and mortality in this devastating pandemic.
\end{abstract}

Keywords Vitamin D · Calcitriol · Innate immunity · Adaptive immunity $\cdot$ Pulmonary alveolar macrophage · Airway epithelia $\cdot$ Viral infection $\cdot$ Cathelicidin

\section{Introduction}

At the time of writing (June 1, 2021) SARS-CoV2, the virus causing the Covid-19 pandemic has infected nearly 275 million people causing approximately 5.4 million deaths world wide, with more each day. Because testing and/or reporting is spotty in a number of countries, the likely count is much higher. The clinical and immunologic features of Covid-19 are only recently being examined given its recent appearance [1], but the findings bear close resemblance to the SARSCoV1 epidemic from 2002-2003, about which more is known. SARS-CoV1 and 2 share approximately $80 \%$ homology [2]. Therefore, it is useful to review the immunologic consequences of the better studied SARs-CoV1 infection,

Daniel D. Bikle

Daniel.bikle@ucsf.edu

1 Veterans Affairs Medical Center and University of California San Francisco, 4150 Clement Street (111N), San Francisco, CA 94121, USA primarily from animal studies, as a background for examining how vitamin D signaling might play a role in the current epidemic. That said Chu et al. [3] noted in bronchial pulmonary lavage material from patients with either SARS-CoV1 or SARS-CoV2 that the SARS-CoV2 virus infected and replicated faster in alveolar pneumocytes and macrophages than did SARS-CoV1 but did not induce interferons and other proinflammatory cytokines as well, perhaps accounting for its overall greater infectivity but lower mortality.

The SARS-CoV2 virus enters the cell via its spike protein, which has two functional subunits. The S1 subunit binds the receptor, the enzyme ACE2 (angiotensin converting enzyme 2). The other subunit, S2, promotes the fusion of the viral and host membrane leading to its internalization. Epithelial cells of the upper airway have the highest concentration of ACE2, but those of the lower airway (alveolar pneumocytes) do as well $[4,5]$. Thus, if the infection is confined to the upper airways the subject may remain asymptomatic although infectious. Moreover, the lower expression of ACE2 in the nasal epithelium of younger children has 
been postulated as a reason for their decreased infection rate compared to older children and adults [6, 7]. In addition to ACE2, the serine protease TMPRSS2 also appears necessary to cleave the SARS-CoV2 protein enabling its membrane fusion and endocytosis. Co-expression of both ACE2 and TMPRSS2 is found in only a small percentage of epithelial cells in both the upper and lower respiratory tract $[4$, 8]. However, ACE2 also serves a protective role. It cleaves angiotensin II to angiotensin 1-7, limiting renin angiotensin system (RAS), which can suppress inflammation and fibrosis while increasing vasodilatation by binding to the MAS receptor. Mice lacking ACE2 undergo severe lung injury [9]. SARS-CoV2 infection reduces ACE2 levels [10], possibly contributing to its inflammatory capacity. On the other hand vitamin D increases ACE2 expression while inhibiting the RAS system [11] thought to contribute to its role in preventing lung injury during viral infections. Therefore, the jury is out regarding the role of ACE2 levels in SARS-CoV2 infections, and its role may differ between the upper and lower respiratory tract.

The serious damage caused by coronaviruses such as SARS-CoV1 and 2 is due to their infection of the lower airways with rapid virus replication, massive inflammatory cell infiltration producing a huge increase in proinflammatory cytokines and chemokines leading to acute respiratory distress syndrome (ARDS), the major cause of morbidity and mortality [12]. The initial infection of the airway epithelium leads to rapid viral replication $[13,14]$ complicated by a virus induced delayed increase in class 1 interferon $(\mathrm{IFN} \alpha / \beta)$ expression in dendritic cells (DC) that would normally block viral replication and enhance viral clearance by CD8 T cells [15]. The delayed expression of IFN $\alpha / \beta$ subsequently increases recruitment of proinflammatory cells, contributing to the problem. These infected airway epithelial cells then secrete a number of proinflammatory cytokines/ chemokines that further dysregulate the innate immune response and attract the influx of inflammatory cells including neutrophils, monocytes and macrophages while sensitizing $\mathrm{T}$ cells to apoptosis [16]. The consequences include a breakdown in the microvascular and alveolar epithelial barrier from apoptosis of the lung epithelium and endothelium resulting in vascular leakage and alveolar edema. The T cell response required for viral clearance is blunted [17], and their role in dampening the cytokine storm is reduced. However, recent studies evaluating cells from bronchopulmonary lavage (BAL) of patients infected with SARS-CoV2 vs other organisms using single cell RNA-seq to define the different cell populations and what they expressed observed that in severe SARS-CoV2 pneumonia there was a high number of $\mathrm{T}$ cells thought to be recruited by infected macrophages expressing cytokines and chemokines such as CCL4 and CXCL10 that in turn expressed proinflammatory cytokines such as interferon-gamma (IFN $\gamma$ ) that further stimulated the inflammatory macrophages $[18,19]$. Moreover, SARS-CoV2 infection increases the numbers of myeloid derived suppressor cells in the lungs that could contribute to suppression of the immune response to the initial infection allowing the infection to spread [20]. So where does vitamin D fit in?

\section{Vitamin D and viral respiratory tract infections}

Vitamin D insufficiency has been linked to increased risk of respiratory tract infections including SARS-CoV2 in a large number of association studies [21-29], whereas vitamin D supplementation appears to be protective especially in those with low levels of 25OHD at baseline and treated with modest doses at daily or weekly intervals [28, 30,31]. Similarly, certain vitamin D receptor (VDR) polymorphisms have been associated with increased risk of acute lower respiratory tract infections [32]. However, the results from randomized clinical trials (RCTs) examining the ability of vitamin D supplementation to limit viral infections have been mixed, as recently reviewed [28, 33]. Vitamin D insufficiency has also been associated with a large number of other viral infections including EBV, VZV, CMV, RSV, HIV, HCV, HBV, HPV, Dengue [33, 34], but until RCTs determine whether the lower levels of 25OHD (marker of vitamin D insufficiency) are causal vs consequential (reverse causality), the role of vitamin $\mathrm{D}$ in these diseases remains uncertain. To this point, a mendelian randomization study which attempted to circumvent the problem of reverse causality by evaluating whether single nucleotide polymorphisms (SNPs) associated with 25OHD levels in genome wide association studies (GWAS) differed between patients infected with SARS-CoV2 and the general population did not find a correlation between those SNPs associated with 25OHD levels and infection rates [35].

\section{Pulmonary immune defense mechanisms and their regulation by vitamin D signaling}

The respiratory tract has a large surface area (approximately $70 \mathrm{~m}^{2}$ ) in contact with the environment. Thus it provides a major site for invasion by pathogenic organisms, against which it must defend. The defense mechanism is comprised of both innate and adaptive immunity. Activation of the innate immune system drives activation of the long term adaptive immune system [36]. The principal cells involved are the airway epithelia, alveolar macrophages, and dendritic cells (DC). All of these cells express CYP27B1, the enzyme producing $1,25(\mathrm{OH})_{2} \mathrm{D}$, the active metabolite of vitamin $\mathrm{D}$, 
as well as the vitamin D receptor (VDR) [37-39]. Expression of CYP27B1 is constitutive in airway epithelial cells [37], although it can be further increased by some types of viral infection [40]. The $1,25(\mathrm{OH})_{2} \mathrm{D}$ produced by these cells promotes alveolar epithelial cell proliferation and reduces their apoptosis after an inflammatory challenge [41]. Deletion of VDR from these cells leads to loss of integrity of the epithelium [42]. On the other hand CYP27B1 is induced in alveolar macrophages by toll like receptor (TLR) ligands for TLR1/2 (such as the lipopeptide from mycobacterium tuberculosis), interferon $\gamma$ (IFN $\gamma$ ), and LPS [43, 44], and in DC by TNF $\alpha$, IFN $\gamma$, polyI:C, and LPS [45-47]. Moreover, these cells all express pattern recognition receptors (PRRs) of which TLRs are a major component and by which viral RNAs are recognized [48].

Innate immune response The innate immune response is initiated with the activation of PRRs in the cells of the respiratory tract. There are 10 functional TLRs in human cells (of 11 known mammalian TLRs). TLRs are an extended family of host noncatalytic transmembrane PRRs that interact with specific membrane patterns (PAMP) shed by infectious agents such as viruses that trigger the innate immune response in the host. A number of these TLRs signal through adapter molecules such as myeloid differentiation factor- 88 (MyD88) and the TIR-domain containing adapter inducing IFN- $\beta$ (TRIF). MyD88 signaling includes translocation of NFKB to the nucleus, leading to the production and secretion of a number of inflammatory cytokines. Indeed one of the anti-inflammatory actions of $1,25(\mathrm{OH})_{2} \mathrm{D}$ is to block NFкB translocation to the nucleus where it would otherwise induce a panel of proinflammatory cytokines. This is achieved in part by inducing the inhibitor for NFKB translocation, ІкB $\alpha$, that binds NFKB and keeps it in the cytoplasm [49]. This effect of $1,25(\mathrm{OH})_{2} \mathrm{D}$ does not deter its influence on viral clearance [50]. TRIF signaling leads to the activation of interferon regulatory factor-3 (IRF-3) and the induction of type 1 interferons such as IFN $\alpha / \beta$. MyD88 mediates signaling from TLRs 2, 4, 5, 7 and 9, whereas TRIF mediates signaling from TLR 3 and 4. TLR1/2, TLR4, TLR5, TLR2/6 respond to bacterial ligands, whereas TLR3, TLR7, and TLR 8 respond to viral ligands. CD14 serves as a coreceptor for a number of these TLRs. CD14 is induced by $1,25(\mathrm{OH})_{2} \mathrm{D}$ [37]. Activation of TLRs leads to the induction of antimicrobial peptides (AMPs) and reactive oxygen species (ROS), which kill the organism. However, excess ROS can also cause cell damage. $1,25(\mathrm{OH})_{2} \mathrm{D}$ can control this process by inducing antioxidant genes such as glutathione synthase [51]. Among the antimicrobial peptides produced by the activated cells is cathelicidin. Cathelicidin plays a number of roles in the innate immune response. The precursor protein, hCAP18, must be cleaved to its major peptide LL-37 to be active. In addition to its antimicrobial properties, LL-37 can stimulate the release of cytokines such as IL-6 and IL-10 through G protein coupled receptors, and IL-18 through ERK/P38 pathways, stimulate the EGF receptor leading to activation of STAT1 and 3, modulate TLR signaling including enhanced recognition of dsRNA, increase binding of dsRNA binding to cell surface scavenger receptors increasing endocytosis, induce the chemotaxis of neutrophils, monocytes, macrophages, and $\mathrm{T}$ cells into the site of infection, and promote the clearance of respiratory pathogens by inducing apoptosis and autophagy of infected epithelial cells $[34,52]$. The expression of this antimicrobial peptide is induced by $1,25(\mathrm{OH})_{2} \mathrm{D}$ in both myeloid and epithelial cells [53-55]. 1,25(OH) $)_{2} \mathrm{D}$ also induces another AMP, defensin $\beta 2$, albeit somewhat indirectly as it involves induction of NOD2/card15/IBD1, a pattern recognition receptor for muramyl dipeptide that in turn activates NOD2 to stimulate $\mathrm{NF \kappa B}$, the direct inducer of defensin $\beta 2$ [56]. Defensin $\beta 2$, like cathelicidin, contributes to host defense by stimulating the expression of antiviral cytokines such as IFN $\beta$, immune inducing molecules (NOD2, TNF $\alpha$, IL-1 $\beta$, IL-6), and chemokines involved in the recruitment of monocytes/macrophages, natural killer cells, neutrophils, $\mathrm{T}$ cells and DC [57]. In summary the innate immune system is the first line of defense against invading pathogens initiating the inflammatory response and activating the adaptive arm of the immune defense mechanism [58]. However, chronic activation of the innate immune response can be deleterious. $1,25(\mathrm{OH})_{2} \mathrm{D}$ inhibits TLR2, 4,9 expression in monocytes in the later stages of activation $[59,60]$ and limits the excessive production of TNF $\alpha$ and IL-12 [61] serving to modulate chronic innate immune activity. But an additional part of the cytokine storm is due to an uncontrolled adaptive immune system, which vitamin D signaling is also poised to modulate.

Adaptive immune response The adaptive immune response is initiated by cells specialized in antigen presentation, DC and macrophages in particular, activating the cells responsible for subsequent antigen recognition, $\mathrm{T}$ and $\mathrm{B}$ lymphocytes. These cells are capable of a wide repertoire of responses that ultimately determine the nature and duration of the immune response. Activation of $\mathrm{T}$ and $\mathrm{B}$ cells occurs after a priming period in tissues of the body, eg. lymph nodes, distant from the site of the initial exposure to the antigenic substance, and is marked by proliferation of the activated $\mathrm{T}$ and $\mathrm{B}$ cells accompanied by post translational modifications of immunoglobulin production that enable the cellular response to adapt specifically to the antigen presented. I will not focus on the role of B cell activation and immunoglobulin production, but limit this discussion to the $\mathrm{T}$ cells. The type of $\mathrm{T}$ cell activated, CD4 or CD8, or within the helper T cell class Th1, Th2, Th17, Treg, and subtle variations of those, is dependent on the context of the 
antigen presented by which cell and in what environment. Systemic factors such as vitamin D influence this process. $1,25(\mathrm{OH})_{2} \mathrm{D}$ in general exerts an inhibitory action on the adaptive immune system. When airway DC are activated as by a virus, they migrate to lymph nodes where they gain enhanced ability to present antigen for activation of $\mathrm{T}$ cells [62]. As noted previously this activation and maturation of DC includes increased CYP27B1 expression but also a decrease in VDR [46]. 1,25(OH $)_{2} \mathrm{D}$ decreases the maturation of DC as marked by inhibited expression of the costimulatory molecules HLA-DR, CD40, CD80, and CD86, decreasing their ability to present antigen and so activate $\mathrm{T}$ cells [63]. Furthermore, by suppressing IL-12 production, important for Th1 development, and IL-23 and IL-6 production important for Th17 development and function, $1,25(\mathrm{OH})_{2} \mathrm{D}$ inhibits the development of Th1 cells capable of producing IFN $\gamma$ and IL-2, and Th17 cells producing IL-17 [64]. These actions prevent further antigen presentation to and recruitment of T lymphocytes (role of IFN $\gamma$ ), and T lymphocyte proliferation (role of IL-2). Furthermore, suppression of IL-12 increases the development of Th2 cells leading to increased IL-4, IL-5, and IL-13 production, which further suppress Th 1 development shifting the balance to a Th 2 cell dominated profile. Treatment of DCs with $1,25(\mathrm{OH})_{2} \mathrm{D}$ can also induce CD4 +/CD25 + regulatory T cells (Treg) cells [65] as shown by increased FoxP3 expression, critical for Treg development [64]. These cells produce IL-10, which suppresses the development of the other Th subclasses. Treg are critical for the induction of immune tolerance [66] and likely play a key role in preventing the cytokine storm associated with severe respiratory disease caused by viral infections such as SARS-CoV2 [67]. On the other hand myeloid suppressor cells, that are increased in SARS-CoV1 infections, may suppress the initial immune response to the infection, facilitating its spread. These cells like other immune cells express VDR, and $1,25(\mathrm{OH})_{2} \mathrm{D}$ blocks their differentiation and so their suppressive action [20].

$1,25(\mathrm{OH})_{2} \mathrm{D}$ has both direct and indirect effects on regulation of a number of key cytokines involved with the proinflammatory response. TNF $\alpha$ has a vitamin D response element (VDRE) in its promoter to which the VDR/RXR complex binds, leading to its repression. As noted earlier $1,25(\mathrm{OH})_{2} \mathrm{D}$ both blocks the activation of NFкB via an increase in ІкB $\alpha$ expression and impedes its binding to its response elements in the proinflammatory genes such as IL-8 and IL-12 that it regulates. $1,25(\mathrm{OH})_{2} \mathrm{D}$ has also been shown to bring an inhibitor complex containing histone deacetylase 3 (HDAC3) to the promoter of rel $\mathrm{B}$, one of the members of the NFKB family, suppressing gene expression. Thus, TNF/NFkB activity is markedly impaired by $1,25(\mathrm{OH})_{2} \mathrm{D}$ at multiple levels. Furthermore,
$1,25(\mathrm{OH})_{2} \mathrm{D}$ suppresses IFN $\gamma$, and a negative VDRE has been found in the IFN $\gamma$ promoter. GM-CSF is regulated by VDR monomers binding to a repressive complex in the promoter of this gene, competing with nuclear factor of $\mathrm{T}$ cells 1(NFAT1) for binding to the promoter. As implied in the introduction, we do not know how much of the knowledge gained about vitamin $\mathrm{D}$ regulated immunity in other systems applies to SARS-CoV2 infections given its recent appearance on the scene, but these studies do underlie the hope that vitamin D will be of some help in the prevention/ treatment of this pandemic given how few other interventions with the exception of vaccination and perhaps newly developed oral antivirals are proving useful.

\section{Conclusion}

While the data clearly demonstrating a beneficial role for vitamin D in SARS-CoV2 infections are limited, its role in regulating both the innate and adaptive immune systems certainly suggests that it may be. The innate immune system is the first line of defense against invading pathogens such as viruses. It is prebuilt, relying on constitutive expression of pattern recognition receptors like TLRs to identify such pathogens. $1,25(\mathrm{OH})_{2} \mathrm{D}$ enhances that defense by inducing AMPs like cathelicidin that lead to viral destruction and clearance by several mechanisms, help recruit neutrophils, monocytes/macrophages, and DC which further the killing and clearance of these pathogens, and initiate the adaptive immune response. While beneficial acutely, chronic activation of the innate immune response is not, and can result in the cytokine storm. $1,25(\mathrm{OH})_{2} \mathrm{D}$ works to curtail this chronic innate immune response through a number of mechanisms including down regulation of TLRs and direct inhibition of TNF/NFKB and IFN $\gamma$ signaling pathways. The adaptive immune system provides a more specific response, but takes longer to develop, although once developed provides a powerful response against invading organisms. However, this response if not controlled can also be destructive. Vitamin $\mathrm{D}$, via its active metabolite $1,25(\mathrm{OH})_{2} \mathrm{D}$, regulates adaptive immunity by limiting the maturation of DC, limiting their ability to present antigen to $\mathrm{T}$ cells, and shifting the $\mathrm{T}$ cell profile from the proinflammatory Th1 and Th17 subsets to Th4 and Treg subsets, which inhibit the proinflammatory processes. Although these results come from studies with a variety of pathogens, viral and bacterial, the relevance of these protective actions on SARS-CoV2 merits further investigation.

Acknowledgements This work was supported by grants RO1 AR055924 from the National Institutes of Health, and I01 BX003814 from the Department of Veterans Affairs.

Funding Funding sources VA I01 BX003814 (DDB); NIH RO1 AR055924. 


\section{Declarations}

Conflicts of interests/competing interests The author has nothing to disclose.

Open Access This article is licensed under a Creative Commons Attribution 4.0 International License, which permits use, sharing, adaptation, distribution and reproduction in any medium or format, as long as you give appropriate credit to the original author(s) and the source, provide a link to the Creative Commons licence, and indicate if changes were made. The images or other third party material in this article are included in the article's Creative Commons licence, unless indicated otherwise in a credit line to the material. If material is not included in the article's Creative Commons licence and your intended use is not permitted by statutory regulation or exceeds the permitted use, you will need to obtain permission directly from the copyright holder. To view a copy of this licence, visit http://creativecommons.org/licenses/by/4.0/.

\section{References}

1. Chen G, Wu D, Guo W, Cao Y, Huang D, Wang H, Wang T, Zhang X, Chen H, Yu H, Zhang X, Zhang M, Wu S, Song J, Chen T, Han M, Li S, Luo X, Zhao J, Ning Q. Clinical and immunological features of severe and moderate coronavirus disease 2019. J Clin Invest. 2020;130(5):2620-9.

2. Zhou P, Yang XL, Wang XG, Hu B, Zhang L, Zhang W, Si HR, Zhu Y, Li B, Huang CL, Chen HD, Chen J, Luo Y, Guo H, Jiang RD, Liu MQ, Chen Y, Shen XR, Wang X, Zheng XS, Zhao K, Chen QJ, Deng F, Liu LL, Yan B, Zhan FX, Wang YY, Xiao GF, Shi ZL. A pneumonia outbreak associated with a new coronavirus of probable bat origin. Nature. 2020;579(7798):270-3.

3. Chu H, Chan JF, Wang Y, Yuen TT, Chai Y, Hou Y, Shuai H, Yang D, Hu B, Huang X, Zhang X, Cai JP, Zhou J, Yuan S, Kok KH, To KK, Chan IH, Zhang AJ, Sit KY, Au WK, Yuen KY. Comparative replication and immune activation profiles of SARSCoV-2 and SARS-CoV in human lungs: An ex vivo study with implications for the pathogenesis of COVID-19. Clin Infect Dis. 2020;71(6):1400-9.

4. Sungnak W, Huang N, Becavin C, Berg M, Queen R, Litvinukova M, Talavera-Lopez C, Maatz H, Reichart D, Sampaziotis F, Worlock KB, Yoshida M, Barnes JL, Network HCALB. SARS-CoV-2 entry factors are highly expressed in nasal epithelial cells together with innate immune genes. Nat Med. 2020;26(5):681-7.

5. Hou YJ, Okuda K, Edwards CE, Martinez DR, Asakura T, Dinnon KH 3rd, Kato T, Lee RE, Yount BL, Mascenik TM, Chen G, Olivier KN, Ghio A, Tse LV, Leist SR, Gralinski LE, Schafer A, Dang H, Gilmore R, Nakano S, Sun L, Fulcher ML, Livraghi-Butrico A, Nicely NI, Cameron M, Cameron C, Kelvin DJ, de Silva A, Margolis DM, Markmann A, Bartelt L, Zumwalt R, Martinez FJ, Salvatore SP, Borczuk A, Tata PR, Sontake V, Kimple A, Jaspers I, O'Neal WK, Randell SH, Boucher RC, Baric RS. SARS-CoV-2 reverse genetics reveals a variable infection gradient in the respiratory tract. Cell. 2020;182(2):429-46.

6. Bunyavanich S, Do A, Vicencio A. Nasal gene expression of angiotensin-converting enzyme 2 in children and adults. JAMA. 2020;323(23):2427-9.

7. Castagnoli R, Votto M, Licari A, Brambilla I, Bruno R, Perlini S, Rovida F, Baldanti F, Marseglia GL. Severe acute respiratory syndrome coronavirus 2 (SARS-CoV-2) Infection in children and adolescents: a systematic review. JAMA Pediatr. 2020;174(9):882-9.

8. Ziegler CGK, Allon SJ, Nyquist SK, Mbano IM, Miao VN, Tzouanas CN, Cao Y, Yousif AS, Bals J, Hauser BM, Feldman
J, Muus C, Wadsworth MH II, Kazer SW, Hughes TK, Doran B, Gatter GJ, Vukovic M, Taliaferro F, Mead BE, Guo Z, Wang JP, Gras D, Plaisant M, Ansari M, Angelidis I, Adler H, Sucre JMS, Taylor CJ, Lin B, Waghray A, Mitsialis V, Dwyer DF, Buchheit KM, Boyce JA, Barrett NA, Laidlaw TM, Carroll SL, Colonna L, Tkachev V, Peterson CW, Yu A, Zheng HB, Gideon HP, Winchell CG, Lin PL, Bingle CD, Snapper SB, Kropski JA, Theis FJ, Schiller HB, Zaragosi LE, Barbry P, Leslie A, Kiem HP, Flynn JL, Fortune SM, Berger B, Finberg RW, Kean LS, Garber M, Schmidt AG, Lingwood D, Shalek AK, OrdovasMontanes J. lung-network@ humancellatlas.org HCALBNEa, network HCALB SARS-CoV-2 receptor ACE2 is an interferonstimulated gene in human airway epithelial cells and is detected in specific cell subsets across tissues. Cell. 2020;181(5):1016-35.

9. Imai Y, Kuba K, Rao S, Huan Y, Guo F, Guan B, Yang P, Sarao R, Wada T, Leong-Poi H, Crackower MA, Fukamizu A, Hui CC, Hein L, Uhlig S, Slutsky AS, Jiang C, Penninger JM. Angiotensinconverting enzyme 2 protects from severe acute lung failure. Nature. 2005;436(7047):112-6.

10. Kumar R, Rathi H, Haq A, Wimalawansa SJ, Sharma A. Putative roles of vitamin $\mathrm{D}$ in modulating immune response and immunopathology associated with COVID-19. Virus Res. 2021;292:198235.

11. Xu J, Yang J, Chen J, Luo Q, Zhang Q, Zhang H. Vitamin D alleviates lipopolysaccharideinduced acute lung injury via regulation of the reninangiotensin system. Mol Med Rep. 2017;16(5):7432-8.

12. Channappanavar R, Perlman S. Pathogenic human coronavirus infections: causes and consequences of cytokine storm and immunopathology. Semin Immunopathol. 2017;39(5):529-39.

13. Chu CM, Poon LL, Cheng VC, Chan KS, Hung IF, Wong MM, Chan KH, Leung WS, Tang BS, Chan VL, Ng WL, Sim TC, Ng PW, Law KI, Tse DM, Peiris JS, Yuen KY. Initial viral load and the outcomes of SARS. CMAJ. 2004;171(11):1349-52.

14. Oh MD, Park WB, Choe PG, Choi SJ, Kim JI, Chae J, Park SS, Kim EC, Oh HS, Kim EJ, Nam EY, Na SH, Kim DK, Lee SM, Song KH, Bang JH, Kim ES, Kim HB, Park SW, Kim NJ. Viral load kinetics of MERS coronavirus infection. N Engl J Med. 2016;375(13):1303-5.

15. Kohlmeier JE, Cookenham T, Roberts AD, Miller SC, Woodland DL. Type I interferons regulate cytolytic activity of memory CD8(+) T cells in the lung airways during respiratory virus challenge. Immunity. 2010;33(1):96-105.

16. Channappanavar R, Fehr AR, Vijay R, Mack M, Zhao J, Meyerholz DK, Perlman S. Dysregulated type I interferon and inflammatory monocyte-macrophage responses cause lethal pneumonia in SARSCoV-infected mice. Cell Host Microbe. 2016;19(2):181-93.

17. Zhao J, Zhao J, Perlman S. T cell responses are required for protection from clinical disease and for virus clearance in severe acute respiratory syndrome coronavirus-infected mice. J Virol. 2010;84(18):9318-25.

18. Grant RA, Morales-Nebreda L, Markov NS, Swaminathan S, Querrey M, Guzman ER, Abbott DA, Donnelly HK, Donayre A, Goldberg IA, Klug ZM, Borkowski N, Lu Z, Kihshen H, Politanska Y, Sichizya L, Kang M, Shilatifard A, Qi C, Lomasney JW, Argento AC, Kruser JM, Malsin ES, Pickens CO, Smith SB, Walter JM, Pawlowski AE, Schneider D, Nannapaneni P, Abdala-Valencia H, Bharat A, Gottardi CJ, Budinger GRS, Misharin AV, Singer BD, Wunderink RG, Investigators NSS. Circuits between infected macrophages and T cells in SARS-CoV-2 pneumonia. Nature. 2021;590(7847):635-41.

19. Liao M, Liu Y, Yuan J, Wen Y, Xu G, Zhao J, Cheng L, Li J, Wang X, Wang F, Liu L, Amit I, Zhang S, Zhang Z. Single-cell landscape of bronchoalveolar immune cells in patients with COVID19. Nat Med. 2020;26(6):842-4.

20. Kloc M, Ghobrial RM, Lipinska-Opalka A, Wawrzyniak A, Zdanowski R, Kalicki B, Kubiak JZ. Effects of vitamin D on 
macrophages and myeloid-derived suppressor cells (MDSCs) hyperinflammatory response in the lungs of COVID-19 patients. Cell Immunol. 2021;360:104259.

21. Cannell JJ, Vieth R, Umhau JC, Holick MF, Grant WB, Madronich S, Garland CF, Giovannucci E. Epidemic influenza and vitamin D. Epidemiol Infect. 2006;134(6):1129-40.

22. Cannell JJ, Zasloff M, Garland CF, Scragg R, Giovannucci E. On the epidemiology of influenza. Virol J. 2008;5:29.

23. Ginde AA, Mansbach JM, Camargo CA Jr. Association between serum 25-hydroxyvitamin D level and upper respiratory tract infection in the third national health and nutrition examination survey. Arch Intern Med. 2009;169(4):384-90.

24. Laaksi I, Ruohola JP, Tuohimaa P, Auvinen A, Haataja R, Pihlajamaki H, Ylikomi T. An association of serum vitamin D concentrations $<40 \mathrm{nmol} / \mathrm{L}$ with acute respiratory tract infection in young finnish men. Am J Clin Nutr. 2007;86(3):714-7.

25. Wayse V, Yousafzai A, Mogale K, Filteau S. Association of subclinical vitamin D deficiency with severe acute lower respiratory infection in Indian children under 5 y. Eur J Clin Nutr. 2004;58(4):563-7.

26. Hernandez JL, Nan D, Fernandez-Ayala M, Garcia-Unzueta M, Hernandez-Hernandez MA, Lopez-Hoyos M, Munoz-Cacho $\mathrm{P}$, Olmos JM, Gutierrez-Cuadra M, Ruiz-Cubillan JJ, Crespo J, Martinez-Taboada VM. Vitamin D status in hospitalized patients with SARS-CoV-2 infection. J Clin Endocrinol Metab. 2021;106(3):e1343-53.

27. Ali N. Role of vitamin D in preventing of COVID-19 infection, progression and severity. J Infect Public Health. 2020;13(10):1373-80.

28. Bassatne A, Basbous M, Chakhtoura M, El Zein O, Rahme M, El-Hajj Fuleihan G. The link between COVID-19 and VItamin D (VIVID): A systematic review and meta-analysis. Metabolism. 2021;119:154753.

29. Maghbooli Z, Sahraian MA, Ebrahimi M, Pazoki M, Kafan S, Tabriz HM, Hadadi A, Montazeri M, Nasiri M, Shirvani A, Holick MF. Vitamin D sufficiency, a serum 25-hydroxyvitamin D at least $30 \mathrm{ng} / \mathrm{mL}$ reduced risk for adverse clinical outcomes in patients with COVID-19 infection. PLoS ONE. 2020;15(9):e0239799.

30. Jolliffe DA, Camargo CA Jr, Sluyter JD, Aglipay M, Aloia JF, Ganmaa D, Bergman P, Bischoff-Ferrari HA, Borzutzky A, Damsgaard CT, Dubnov-Raz G, Esposito S, Gilham C, Ginde AA, Golan-Tripto I, Goodall EC, Grant CC, Griffiths CJ, Hibbs AM, Janssens W, Khadilkar AV, Laaksi I, Lee MT, Loeb M, Maguire JL, Majak P, Mauger DT, Manaseki-Holland S, Murdoch DR, Nakashima A, Neale RE, Pham H, Rake C, Rees JR, Rosendahl J, Scragg R, Shah D, Shimizu Y, Simpson-Yap S, Trilok-Kumar G, Urashima M, Martineau AR. Vitamin D supplementation to prevent acute respiratory infections: a systematic review and metaanalysis of aggregate data from randomised controlled trials. Lancet Diabetes Endocrinol. 2021;9(5):276-92.

31. Drame M, Cofais C, Hentzien M, Proye E, Coulibaly PS, Demoustier-Tampere D, Destailleur MH, Lotin M, Cantagrit E, Cebille A, Desprez A, Blondiau F, Kanagaratnam L, Godaert L. Relation between vitamin D and COVID-19 in aged people: A systematic review. Nutrients. 2021;13:4.

32. Roth DE, Jones AB, Prosser C, Robinson JL, Vohra S. Vitamin $D$ receptor polymorphisms and the risk of acute lower respiratory tract infection in early childhood. J Infect Dis. 2008;197(5):676-80.

33. Grant WB, Lahore H, McDonnell SL, Baggerly CA, French CB, Aliano JL, Bhattoa HP. Evidence that vitamin D supplementation could reduce risk of influenza and COVID-19 infections and deaths. Nutrients. 2020;12:4.

34. Teymoori-Rad M, Shokri F, Salimi V, Marashi SM. The interplay between vitamin D and viral infections. Rev Med Virol. 2019;29(2):e2032.
35. Patchen BK, Clark AG, Gaddis N, Hancock DB, Cassano PA. Genetically predicted serum vitamin D and COVID-19: a Mendelian randomisation study. BMJ Nutr Prev Health. 2021 May 4;4(1):213-225. https://doi.org/10.1136/bmjnph-2021-000255. eCollection 2021.

36. Iwasaki A, Medzhitov R. Regulation of adaptive immunity by the innate immune system. Science. 2010;327(5963):291-5.

37. Hansdottir S, Monick MM, Hinde SL, Lovan N, Look DC, Hunninghake GW. Respiratory epithelial cells convert inactive vitamin D to its active form: potential effects on host defense. J Immunol. 2008;181(10):7090-9.

38. Hansdottir S, Monick MM. Vitamin D effects on lung immunity and respiratory diseases. Vitam Horm. 2011;86:217-37.

39. Mathyssen C, Aelbrecht C, Serre J, Everaerts S, Maes K, GayanRamirez G, Vanaudenaerde B, Janssens W. Local expression profiles of vitamin D-related genes in airways of COPD patients. Respir Res. 2020;21(1):137.

40. Telcian AG, Zdrenghea MT, Edwards MR, Laza-Stanca V, Mallia P, Johnston SL, Stanciu LA. Vitamin D increases the antiviral activity of bronchial epithelial cells in vitro. Antiviral Res. 2017;137:93-101.

41. Zheng S, Yang J, Hu X, Li M, Wang Q, Dancer RCA, Parekh D, Gao-Smith F, Thickett DR, Jin S. Vitamin D attenuates lung injury via stimulating epithelial repair, reducing epithelial cell apoptosis and inhibits TGF-beta induced epithelial to mesenchymal transition. Biochem Pharmacol. 2020;177:113955.

42. Chen H, Lu R, Zhang YG, Sun J. Vitamin D Receptor deletion leads to the destruction of tight and adherens junctions in lungs. Tissue Barriers. 2018;6(4):1-13.

43. Reichel H, Koeffler HP, Barbers R, Norman AW. Regulation of 1,25-dihydroxyvitamin $\mathrm{D} 3$ production by cultured alveolar macrophages from normal human donors and from patients with pulmonary sarcoidosis. J Clin Endocrinol Metab. 1987;65(6):1201-9.

44. Liu PT, Stenger S, Li H, Wenzel L, Tan BH, Krutzik SR, Ochoa MT, Schauber J, Wu K, Meinken C, Kamen DL, Wagner M, Bals R, Steinmeyer A, Zugel U, Gallo RL, Eisenberg D, Hewison M, Hollis BW, Adams JS, Bloom BR, Modlin RL. Toll-like receptor triggering of a vitamin D-mediated human antimicrobial response. Science. 2006;311(5768):1770-3.

45. Fritsche J, Mondal K, Ehrnsperger A, Andreesen R, Kreutz M. Regulation of 25-hydroxyvitamin D3-1 alpha-hydroxylase and production of 1 alpha,25-dihydroxyvitamin D3 by human dendritic cells. Blood. 2003;102(9):3314-6.

46. Hewison M, Freeman L, Hughes SV, Evans KN, Bland R, Eliopoulos AG, Kilby MD, Moss PA, Chakraverty R. Differential regulation of vitamin $D$ receptor and its ligand in human monocyte-derived dendritic cells. J Immunol. 2003;170(11):5382-90.

47. Sigmundsdottir H, Pan J, Debes GF, Alt C, Habtezion A, Soler D, Butcher EC. DCs metabolize sunlight-induced vitamin D3 to program $T$ cell attraction to the epidermal chemokine CCL27. Nat Immunol. 2007;8(3):285-93.

48. Guo XJ, Thomas PG. New fronts emerge in the influenza cytokine storm. Semin Immunopathol. 2017;39(5):541-50.

49. Gonzalez-Pardo V, D'Elia N, Verstuyf A, Boland R, Russo de Boland A. NFkappaB pathway is down-regulated by 1alpha, 25(OH)(2)-vitamin $\mathrm{D}(3)$ in endothelial cells transformed by Kaposi sarcoma-associated herpes virus $\mathrm{G}$ protein coupled receptor. Steroids. 2012;77(11):1025-32.

50. Hansdottir S, Monick MM, Lovan N, Powers L, Gerke A, Hunninghake GW. Vitamin D decreases respiratory syncytial virus induction of NF-kappaB-linked chemokines and cytokines in airway epithelium while maintaining the antiviral state. J Immunol. 2010;184(2):965-74. 
51. Lei GS, Zhang C, Cheng BH, Lee CH. Mechanisms of action of vitamin $\mathrm{D}$ as supplemental therapy for pneumocystis pneumonia. Antimicrob Agents Chemother. 2017;61:10.

52. Yuk JM, Shin DM, Lee HM, Yang CS, Jin HS, Kim KK, Lee ZW, Lee SH, Kim JM, Jo EK. Vitamin D3 induces autophagy in human monocytes/macrophages via cathelicidin. Cell Host Microbe. 2009;6(3):231-43.

53. Gombart AF, Borregaard N, Koeffler HP. Human cathelicidin antimicrobial peptide (CAMP) gene is a direct target of the vitamin $\mathrm{D}$ receptor and is strongly up-regulated in myeloid cells by 1,25-dihydroxyvitamin D3. Faseb J. 2005;19(9):1067-77.

54. Wang TT, Nestel FP, Bourdeau V, Nagai Y, Wang Q, Liao J, TaveraMendoza L, Lin R, Hanrahan JW, Mader S, White JH. Cutting edge: 1,25-dihydroxyvitamin D3 is a direct inducer of antimicrobial peptide gene expression. J Immunol. 2004;173(5):2909-12.

55. Chung C, Silwal P, Kim I, Modlin RL, Jo EK. Vitamin D-cathelicidin axis: at the crossroads between protective immunity and pathological inflammation during infection. Immune Netw. 2020;20(2):e12.

56. Wang TT, Dabbas B, Laperriere D, Bitton AJ, Soualhine H, Tavera-Mendoza LE, Dionne S, Servant MJ, Bitton A, Seidman EG, Mader S, Behr MA, White JH. Direct and indirect induction by 1,25-dihydroxyvitamin D3 of the NOD2/CARD15-defensin beta2 innate immune pathway defective in Crohn disease. J Biol Chem. 2010;285(4):2227-31.

57. Kim J, Yang YL, Jang SH, Jang YS. Human beta-defensin 2 plays a regulatory role in innate antiviral immunity and is capable of potentiating the induction of antigen-specific immunity. Virol J. 2018;15(1):124.

58. Oppenheim JJ, Tewary P, de la Rosa G, Yang D. Alarmins initiate host defense. Adv Exp Med Biol. 2007;601:185-94.

59. Baeke F, Takiishi T, Korf H, Gysemans C, Mathieu C. Vitamin D: modulator of the immune system. Curr Opin Pharmacol. 2010;10(4):482-96.
60. Sadeghi K, Wessner B, Laggner U, Ploder M, Tamandl D, Friedl J, Zugel U, Steinmeyer A, Pollak A, Roth E, Boltz-Nitulescu G, Spittler A. Vitamin D3 down-regulates monocyte TLR expression and triggers hyporesponsiveness to pathogen-associated molecular patterns. Eur J Immunol. 2006;36(2):361-70.

61. Cantorna MT, Yu S, Bruce D. The paradoxical effects of vitamin D on type 1 mediated immunity. Mol Aspects Med. 2008;29(6):369-75.

62. Holt PG, Strickland DH, Wikstrom ME, Jahnsen FL. Regulation of immunological homeostasis in the respiratory tract. Nat Rev Immunol. 2008;8(2):142-52.

63. van Etten E, Mathieu C. Immunoregulation by 1,25-dihydroxyvitamin D3: basic concepts. J Steroid Biochem Mol Biol. 2005;97(1-2):93-101.

64. Daniel C, Sartory NA, Zahn N, Radeke HH, Stein JM. Immune modulatory treatment of trinitrobenzene sulfonic acid colitis with calcitriol is associated with a change of a T helper (Th) $1 / \mathrm{Th} 17$ to a Th2 and regulatory T cell profile. J Pharmacol Exp Ther. 2008;324(1):23-33.

65. Gregori S, Casorati M, Amuchastegui S, Smiroldo S, Davalli AM, Adorini L. Regulatory T cells induced by 1 alpha,25-dihydroxyvitamin D3 and mycophenolate mofetil treatment mediate transplantation tolerance. J Immunol. 2001;167(4):1945-53.

66. Sakaguchi S, Yamaguchi T, Nomura T, Ono M. Regulatory T cells and immune tolerance. Cell. 2008;133(5):775-87.

67. Rudensky AY. Regulatory T cells and Foxp3. Immunol Rev. 2011;241(1):260-8.

Publisher's note Springer Nature remains neutral with regard to jurisdictional claims in published maps and institutional affiliations. 